\title{
Increased Susceptibility to Ischemic Brain Damage in Transgenic Mice Overexpressing the Amyloid Precursor Protein
}

\author{
Fangyi Zhang, ${ }^{1}$ Chris Eckman, ${ }^{2}$ Steven Younkin, ${ }^{2}$ Karen K. Hsiao, ${ }^{1}$ and Costantino ladecola ${ }^{1}$ \\ ${ }^{1}$ Department of Neurology, University of Minnesota, Minneapolis, Minnesota 55455, and ${ }^{2}$ Mayo Clinic Jacksonville, \\ Jacksonville, Florida 32224
}

\begin{abstract}
We studied the role of the amyloid precursor protein (APP) in ischemic brain damage using transgenic mice overexpressing APP. The middle cerebral artery (MCA) was occluded in FVB/N mice expressing $\mathrm{APP}_{695}$.SWE (Swedish mutation) and in nontransgenic littermates. Infarct volume (cubic millimeters) was assessed $24 \mathrm{hr}$ later in thionin-stained brain sections. The infarct produced by MCA occlusion was enlarged in the transgenics ( $+32 \pm 6 \% ; n=12 ; p<0.05 ; t$ test). Measurement of APP by ELISA revealed that, although relatively high levels of $\mathrm{A} \beta$ were present in the brain of the transgenics $\left(\mathrm{A} \beta_{1-40}=80 \pm\right.$ $19 \mathrm{pmol} / \mathrm{g} ; n=6)$, there were no differences between ischemic and nonischemic hemispheres $(p>0.05)$. The reduction in cerebral blood flow produced by MCA occlusion at the periphery of the ischemic territory was more pronounced in APP
\end{abstract}

transgenics $(-42 \pm 8 \% ; n=9)$ than in controls $(-20 \pm 8 \% ; n=$ 9). Furthermore, the vasodilatation produced by neocortical application of the endothelium-dependent vasodilator acetylcholine $(10 \mu \mathrm{M})$ was reduced by $82 \pm 5 \%(n=8 ; p<0.05)$ in APP transgenics. The data demonstrate that APP overexpression increases the susceptibility of the brain to ischemic injury. The effect is likely to involve the $A \beta$-induced disturbance in endothelium-dependent vascular reactivity that leads to more severe ischemia in regions at risk for infarction. The cerebral vascular actions of peptides deriving from APP metabolism may play a role in the pathogenic effects of APP.

Key words: middle cerebral artery; Alzheimer's disease; cerebral ischemia; stroke; cerebral blood flow; transgenic mice
There is substantial evidence that the amyloid precursor protein (APP), a constitutively expressed transmembrane glycoprotein, is involved in the pathogenesis of Alzheimer's dementia (Price and Sisodia, 1994; Selkoe et al., 1996; Mattson et al., 1997). APP is present in different isoforms derived from a single gene by alternative splicing (Lendon et al., 1997). A 39-42 amino acid fragment of APP, $\mathrm{A} \beta$, is present in amyloid plaques in the brain of patients with Alzheimer's disease and Down's syndrome and in normal brain aging (Lendon et al., 1997). Both in vitro and in vivo evidence suggest that $\mathrm{A} \beta$ is cytotoxic, an effect that may depend on the state of aggregation of $\mathrm{A} \beta$ (Mattson et al., 1993a). The mechanisms of the neurotoxicity of $\mathrm{A} \beta$ are thought to include perturbation of ionic homeostasis and free radical production (Mattson et al., 1993a; Fraser et al., 1997).

It has been proposed that APP and $\mathrm{A} \beta$ may also participate in ischemic brain damage. Although APP expression is increased in the postischemic brain (Abe et al., 1991a,b; Stephenson et al., 1992; Wakita et al., 1992; Kalaria et al., 1993; Banati et al., 1995), cerebral ischemia may facilitate cleavage of APP into the toxic A $\beta$ fragment (Saido et al., 1994; Yokota et al., 1996). These observations raise the possibility that ischemia leads to accumulation of $\mathrm{A} \beta$, which, in turn, could contribute to ischemic brain damage. On the other hand, there is also evidence that APP may

\footnotetext{
Received June 13, 1997; revised July 22, 1997; accepted Aug. 5, 1997.

This work was supported by grants from the American Heart Association (C.I.) and National Institutes of Health Grants NS34179, NS31318, and NS35806 (C.I.) and NS33249 (K.K.H.). C.I. is an Established Investigator of the American Heart Association. We thank Dr. Lennart Mucke for his comments, Ms. Sara Love for helping with the transgenic mice, and Ms. Karen MacEwan for editorial assistance. Correspondence should be addressed to Dr. C. Iadecola, Department of Neurology, University of Minnesota, Box 295 UMHC, 420 Delaware Street Southeast, Minneapolis, MN 55455.

Copyright (C) 1997 Society for Neuroscience $0270-6474 / 97 / 177655-07 \$ 05.00 / 0$
}

protect vulnerable neurons from global cerebral ischemia and attenuates neurotoxicity in neuronal cultures (Mattson et al., 1993a; Smith et al., 1994). Therefore, the role of APP in ischemic brain damage has not been elucidated.

The study of the role of APP in cerebral ischemic injury could benefit from recently developed transgenic mice overexpressing different isoforms of APP (e.g., Games et al., 1995; Higgins et al., 1995; Hsiao et al., 1995, 1996). In the present study, therefore, we used APP transgenics to determine whether APP overexpression exacerbates ischemic brain damage and, if so, to establish whether the effect is related to ischemia-induced accumulation of $\mathrm{A} \beta$. We found that occlusion of the middle cerebral artery (MCA) in APP mice produces larger cerebral infarcts than in nontransgenic littermates. The effect is not associated with increased $\mathrm{A} \beta$ levels compared with the contralateral nonischemic brain. In addition, the reduction in cerebral blood flow $(\mathrm{CBF})$ produced by MCA occlusion is more severe in APP transgenics than in controls, although the $\mathrm{CBF}$ increase produced by neocortical application of acetylcholine (ACh) is attenuated in APP transgenics. The data indicate that APP overexpression is deleterious to the postischemic brain. The effect may derive from the neurotoxicity of $\mathrm{A} \beta$ and from $\mathrm{A} \beta$-induced loss of vascular reactivity resulting in more severe ischemia. Therefore, vascular factors have to be taken into account when examining the pathogenic effects of APP and its metabolites on the CNS.

\section{MATERIALS AND METHODS}

\section{Animals}

The APP variant known as the Swedish mutation $\left(\mathrm{APP}_{695} . \mathrm{SWE}\right)$ was overexpressed in $\mathrm{FVB} / \mathrm{N}$ mice using a prion protein cosmid vector (Hsiao et al., 1995). APP mice develop behavioral abnormalities associated with astrogliosis and decreased glucose use in selected telencephalic regions (Hsiao et al., 1995). The transgenics do not exhibit histological 
evidence of $\beta$-amyloid deposits in brain or blood vessels (Hsiao et al., 1995). Mice were studied at age 3-4 months (body weight, 25-30 gm). All mice were genotyped to determine the presence of the transgene. Nontransgenic littermates were used as controls.

\section{Induction of focal cerebral ischemia}

Focal cerebral ischemia was produced by occlusion of the MCA. Techniques for MCA occlusion in mice were similar to those described previously for the rat (Zhang and Iadecola, 1992). Mice were anesthetized with $2 \%$ halothane in $100 \%$ oxygen. Body temperature was maintained at $37 \pm 0.5^{\circ} \mathrm{C}$ by a thermostatically controlled infrared lamp. A 2 $\mathrm{mm}$ hole was drilled in the inferior portion of the temporal bone to expose the left MCA. The MCA was elevated and cauterized distal to the origin of the lenticulostriate branches (Zhang and Iadecola, 1992). Wounds were sutured, and mice were allowed to recover and returned to their cages. Rectal temperature was controlled until mice regained full consciousness. The animals were killed $24 \mathrm{hr}$ after MCA occlusion for measurement of infarct size and for $\mathrm{A} \beta$ determination (see below).

\section{Determination of infarct volume}

Mice were killed for determination of infarct volume $1 \mathrm{~d}$ after MCA occlusion. Brains were removed and frozen in cooled isopentane $\left(-30^{\circ} \mathrm{C}\right)$. Coronal forebrain sections (thickness $\left.30 \mu \mathrm{m}\right)$ were serially cut in a cryostat, collected at $150 \mu \mathrm{m}$ intervals, and stained with thionin for determination of infarct volume by an image analyzer (M1, Imaging Research Inc.) (Zhang and Iadecola, 1992). To factor out the contribution of ischemic swelling to the total volume of the lesion, infarct volume in cerebral cortex was corrected for swelling as described previously (Zhang and Iadecola, 1994; Iadecola et al., 1995). The correction method is based on the determination of ischemic swelling by comparing the volume of ischemic and nonischemic hemispheres (Lin et al., 1993).

\section{Determination of $A \beta$}

APP transgenics were killed $24 \mathrm{hr}$ after MCA occlusion. The infarcted cortex and the contralateral intact cortex were dissected out and frozen in liquid nitrogen and stored at $-80^{\circ} \mathrm{C}$ until analysis. Techniques for $\mathrm{A} \beta$ measurement have been described in detail previously (Suzuki et al., 1994; Gravina et al., 1995) and are summarized. Approximately $0.2 \mathrm{gm}$ of tissue was homogenized in $1 \mathrm{ml}$ of $70 \%$ formic acid and centrifuged at $>100,000 \times g$ for $1 \mathrm{hr}$. The formic acid extract was removed, and a small aliquot was diluted 50 times in $1 \mathrm{~m}$ Tris, $\mathrm{pH}$ 8.0. This sample was then further diluted 2.4 times in buffer EC $(0.02 \mathrm{M}$ sodium phosphate, $\mathrm{pH} 7.0,0.2$ mM EDTA, $0.4 \mathrm{M} \mathrm{NaCl}, 0.2 \%$ bovine serum albumin, $0.05 \% 3-[(3-$ cholamidopropyl)dimethylammonio]-1-propanesulfonic acid, $0.4 \%$ BlockAce, and $0.05 \%$ sodium azide), and $100 \mu \mathrm{l}$ of this solution was analyzed directly using either the BNT77/BA27 or BNT77/BC05 sandwich ELISA system (Suzuki et al., 1994; Gravina et al., 1995). A $\beta$ values were obtained by comparing the absorbance obtained from duplicate samples to standard curves of either $\mathrm{A} \beta_{1-40}\left(\mathrm{BNT77/BA27)}\right.$ or $\mathrm{A} \beta_{1-42}(\mathrm{BNT77/BC05)}$ with a standard curve (Bachem). Absorbance values were corrected for dilution and initial wet weight.

\section{Determination of cerebral blood flow}

Techniques used for studying the cerebral circulation in mice were similar to those described previously (Dalkara et al., 1995; Sobey and Faraci, 1997). Mice were anesthetized with halothane (maintenance 1\%), and the femoral artery and trachea were cannulated. Mice were artificially ventilated with an oxygen-nitrogen mixture by a mechanical ventilator (SAR-830; CWI Inc., Ardmore, PA). The inspiration time was set at $0.1 \mathrm{sec}$, the respiratory rate at $120 / \mathrm{min}$, and the inspiratory flow at $\sim 250 \mathrm{ml} / \mathrm{min}$. The oxygen concentration in the mixture was adjusted to obtain an arterial $\mathrm{P}_{\mathrm{O}_{2}}$ of $150-170$ mmHg. End-tidal $\mathrm{CO}_{2}$ was continuously monitored using a $\mathrm{CO}_{2}$ analyzer (Capstar-100, CWI Inc.). The sample flow rate of the $\mathrm{CO}_{2}$ analyzer was set at $10 \mathrm{cc} / \mathrm{min}$. Great care was taken to accurately monitor arterial $\mathrm{P}_{\mathrm{CO}_{2}}$ and $\mathrm{P}_{\mathrm{O}_{2}}$, critical variables for studies of the cerebral circulation (Heistad and Kontos, 1983). In preliminary studies $(n=10)$, we established the relationship between end-tidal $\mathrm{CO}_{2}$ and arterial $\mathrm{P}_{\mathrm{CO}_{2}}$, measured by a blood gas analyzer (model 178; CIBA-Corning, Medfield, MA). The relationship was linear between $\mathrm{P}_{\mathrm{CO}_{2}}$ values of 31 and $67 \mathrm{mmHg}\left(\mathrm{r}^{2}=0.92 ; p<0.001\right.$; $n=28)$. Throughout the experiment, end-tidal $\mathrm{CO}_{2}$ was maintained at 2.6-2.7\%, which corresponds to a $\mathrm{P}_{\mathrm{CO}_{2}}$ of $33-35 \mathrm{mmHg}$. The $\mathrm{P}_{\mathrm{O}_{2}}$ of the mice was $166 \pm 11$, and the $\mathrm{pH}$ was $7.40 \pm 0.04$.

MCA occlusion. For monitoring of the changes in CBF produced by MCA occlusion, two laser Doppler flow probes (Vasamedic, St. Paul,
$\mathrm{MN}$ ) were placed through burr holes placed in the center ( $3.5 \mathrm{~mm}$ lateral to the midline and $1 \mathrm{~mm}$ caudal to bregma) and the periphery $(1.5 \mathrm{~mm}$ lateral to the midline and $1.7 \mathrm{~mm}$ rostral to lambda) of the ischemic territory (Chan et al., 1993). After placement of the probes, the MCA was occluded, and CBF was monitored for $60 \mathrm{~min}$. CBF data are expressed as a percentage of the preocclusion value.

Cerebrovascular reactivity. Techniques for testing cerebral microvascular reactivity in mice were similar to those described previously in rats (Iadecola, 1992; Iadecola and Zhang, 1996). Mice were anesthetized and instrumented as described above. A cranial window was drilled in the parietal bone to expose the parietal cortex. The dura was removed, and the site was superfused with Ringer's solution $\left(37^{\circ} \mathrm{C} ; \mathrm{pH} 7.3-7.4\right)$. CBF was continuously monitored at the site of superfusion with a laser Doppler probe. After stabilization of arterial pressure and blood gases, ACh (10 $\mu \mathrm{M}$; Sigma, St. Louis, MO) was superfused. After the CBF increase reached a steady state (usually $3-5 \mathrm{~min}$ ), ACh was discontinued, and $\mathrm{CBF}$ returned to baseline. The nitric oxide donor $S$-nitroso- $N$ acetylpenicillamine (SNAP) $(500 \mu \mathrm{M})$ was then topically applied, and the changes in CBF were monitored. The concentrations of ACh and SNAP were the $\mathrm{EC}_{50}$ values, as determined by dose-response curves in preliminary experiments.

\section{Data analysis}

Data in text and figures are expressed as mean \pm SE. Two-group comparisons were analyzed by the two-tailed $t$ test for independent or paired samples as appropriate. $p<0.05$ was considered statistically significant.

\section{RESULTS \\ Effect of MCA occlusion on infarct size in APP transgenics}

In nontransgenic mice $(n=13)$, MCA occlusion distal to the origin of the lenticulostriate arteries produced infarcts involving mainly the cerebral cortex (Figs. 1, 2). Size and distribution of the lesion were comparable to those described previously in wild-type mice (e.g., Barone et al., 1993). In APP transgenics $(n=12)$ the cortical infarcts produced by MCA occlusion were larger $(+32 \pm 6 \%)$ than those of nontransgenic littermates (Figs. 1, 2). The effect persisted after correction for swelling (Fig. $1 A$ ). The volume of brain swelling was $10.8 \pm 1 \mathrm{~mm}^{3}$ in APP transgenics and $10.5 \pm 0.6 \mathrm{~mm}^{3}$ in nontransgenic mice $(p>0.05)$. The area recruited into infarction involved the medial edge of the cortical lesion throughout the rostrocaudal extent of the infarct (Figs. $1 B, 2$ ).

\section{$\mathbf{A} \boldsymbol{\beta}$ concentration in the postischemic brain}

To determine whether cerebral ischemia leads to accumulation of $\mathrm{A} \beta$, we measured $\mathrm{A} \beta$ concentration in the ischemic region of APP transgenic mice $24 \mathrm{hr}$ after MCA occlusion $(n=6)$. In agreement with previous data (Hsiao et al., 1995), transgenederived $\mathrm{A} \beta_{1-40}$ and $\mathrm{A} \beta_{1-42}$ were present in the brain (Fig. 3). However, the concentration of these peptides did not differ between ischemic and nonischemic hemispheres $(p>0.05$, paired $t$ test) (Fig. 3).

\section{Effect of MCA occlusion on CBF in APP transgenics and nontransgenic mice}

We then sought to determine whether the severity of CBF reduction produced by MCA occlusion was comparable in APP transgenics and nontransgenic mice. In these experiments, $\mathrm{CBF}$ was monitored in the center and the periphery of the ischemic territory before and after MCA occlusion. In the center of the ischemic territory, $\mathrm{CBF}$ was reduced by $\sim 80 \%$ of the preischemic level, indicating that the probe was in the ischemic core, a region of severe ischemia in which brain cells die rapidly. At the periphery of the ischemic region, flow was reduced by $30-40 \%$, a reduction consistent with probe placement into the so-called ischemic penumbra, an area of less severe ischemia surrounding 


\section{FVB/N HuAPP695.SWE}
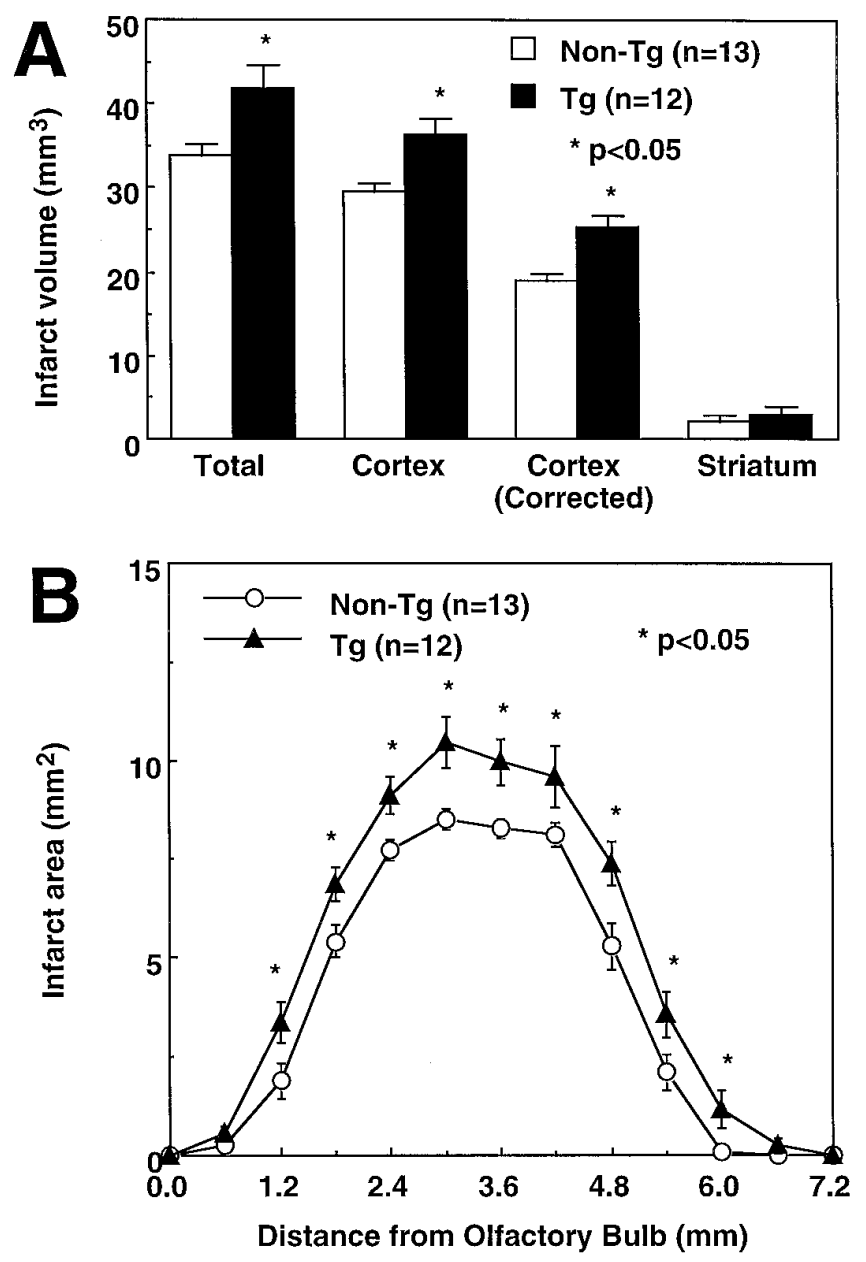

Figure 1. Effect of MCA occlusion on cerebral ischemic damage in $\mathrm{FVB} / \mathrm{N}$ transgenic mice overexpressing $\mathrm{APP}_{695}$.SWE. $A$, MCA occlusion resulted in larger infarcts in APP transgenics than in nontransgenic littermates $(p<0.05, t$ test), an effect that persists after correction for ischemic swelling (corrected). $B$, Rostrocaudal distribution of the ischemic lesion produced by MCA occlusion in APP transgenics and nontransgenic littermates. The enlargement of the lesion occurs both in the anterior and posterior regions of the infarct $(p<0.05)$.

the ischemic core (Hossmann, 1994). Before MCA occlusion, resting CBF was $22.6 \pm 1.7$ perfusion units in APP transgenics and $24.4 \pm 0.9$ in nontransgenics $(p>0.05)$. In the ischemic core, the decrease in $\mathrm{CBF}$ was virtually identical in transgenic $(n=9)$ and nontransgenic mice $(n=9)$ (Fig. 4). However, in the ischemic penumbra the reduction in $\mathrm{CBF}$ was greater in APP mice than in nontransgenic controls $(p<0.05)$ (Fig. 4). These findings demonstrate that APP mice are subjected to a greater flow reduction in the ischemic penumbra, a region at risk for infarction.

\section{Cerebrovascular reactivity in APP transgenics}

The observation that the reduction in $\mathrm{CBF}$ in the penumbra is more marked in APP transgenics suggests that the mechanisms regulating CBF are impaired in APP transgenics. This possibility is supported by the observation that in isolated systemic vessels $\mathrm{A} \beta$ reduces the relaxation produced by $\mathrm{ACh}$ (Thomas et al., 1996). We, therefore, sought to determine whether the reactivity of the cerebral circulation to ACh is impaired in APP transgenics.
Resting CBF was $22.9 \pm 1.8$ perfusion units in APP transgenics and $22.1 \pm 1.9$ in nontransgenic littermates $(\mathrm{p}>0.05)$. In nontransgenic littermates, topical application of ACh $(10 \mu \mathrm{M})$ or SNAP $(500 \mu \mathrm{M})$ increased CBF (Fig. 5). However, the increase in $\mathrm{CBF}$ produced by $\mathrm{ACh}$ was substantially attenuated in APP transgenics, whereas the response to SNAP was not significantly reduced (Fig. 5). These data suggest that selected vasodilator responses of the cerebral circulation are impaired in APP transgenics.

\section{DISCUSSION}

We sought to study the role of APP in ischemic brain damage. Although global or focal cerebral ischemia induces expression of APP in neurons and glia (Abe et al., 1991a,b; Stephenson et al., 1992; Wakita et al., 1992; Kalaria et al., 1993; Banati et al., 1995), the biological significance of the APP upregulation remains unclear. Some studies have suggested that APP expression has a protective role after cerebral ischemia. For example, APP, administered intracerebroventricularly, reduces hippocampal damage after global cerebral ischemia in gerbils (Smith et al., 1994), although in vitro APP protects neurons from excitotoxicity (Mattson et al., 1993b). Other studies, however, have provided evidence that APP may be detrimental to the ischemic brain. For example, the $\mathrm{A} \beta$ peptide, a neurotoxic fragment of APP, has been found to accumulate in vulnerable neurons in the postischemic hippocampus (Yokota et al., 1996). Therefore, it remains to be defined whether APP is protective or destructive in cerebral ischemia.

In the present study, we used transgenic mice overexpressing $\mathrm{APP}_{655}$.SWE to investigate the effect of APP on ischemic brain damage (Hsiao et al., 1995). These mice develop behavioral abnormalities, gliosis, and reduced glucose use in selected telencephalic regions by the time they are 8-12 weeks old (Hsiao et al., 1995). $\mathrm{APP}_{655}$.SWE mice do not develop amyloid deposition in brain or blood vessels (Hsiao et al., 1995). We found that MCA occlusion in APP transgenics results in infarcts that are larger than those of nontransgenic littermates. These observations indicate that APP overexpression in mice is associated with an increased susceptibility to focal cerebral ischemia.

To gain an insight into the mechanism of the increase in infarct size in APP transgenics, we measured $\mathrm{A} \beta$ concentration in the postischemic brain using a sensitive ELISA-based assay (Suzuki et al., 1994; Gravina et al., 1995). The rationale for this approach was that global cerebral ischemia has been reported to increase the cleavage of APP into the A $\beta$ fragment in the gerbil hippocampus (Saido et al., 1994; Yokota et al., 1996). Because the A $\beta$ peptide is thought to be neurotoxic (Mattson et al., 1993a; Fraser et al., 1997), accumulation of $\mathrm{A} \beta$ in the postischemic brain may exacerbate tissue damage. However, although relatively high levels of transgene-derived $A \beta$ were observed in the brain of APP mice, the concentration of this peptide did not differ between ischemic and nonischemic hemispheres. This finding argues against the hypothesis that ischemia increases $A \beta$ cleavage from APP. However, because $\mathrm{A} \beta$ was measured in the entire ischemic region, the possibility of increases in subregions of the infarct cannot be ruled out. Studies in which $\mathrm{A} \beta$ is measured regionally are required to address this issue.

To investigate the role of vascular factors in the increased susceptibility to cerebral ischemia of APP transgenics, we studied the reduction in CBF produced by MCA occlusion in APP mice and controls. It was found that, although in the center of the ischemic territory the flow reduction is virtually identical in transgenic and nontransgenic mice, at the periphery of the infarct 
Non-Tg

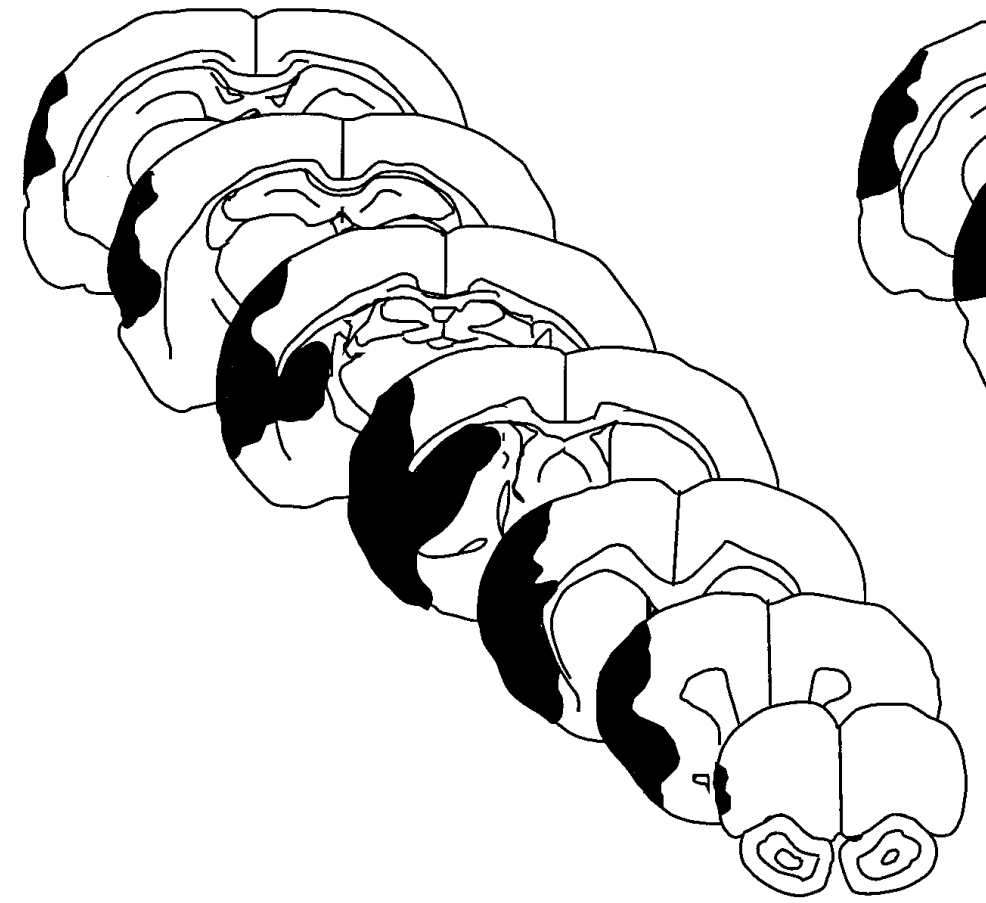

APP Tg

(FVB/N HuAPP695.SWE)

Figure 2. Brain sections from representative animals indicating the distribution of the ischemic lesion in nontransgenic mice (Non-Tg) and in FVB/N transgenic mice overexpressing $\mathrm{APP}_{695} . \mathrm{SWE}\left[A P P T g\left(F V B / N H u A P P_{695} . S W E\right)\right]$. The area recruited into infarction in the transgenics involves the periphery of the lesion uniformly at all rostrocaudal levels.

the degree of oligemia is more marked in APP transgenics. The region in which the flow reduction is more severe overlaps with the area recruited into infarction in the transgenics. This area of the infarct corresponds to the "ischemic penumbra," a region in which the reduction in flow is not severe enough to produce rapid neuronal death (Astrup et al., 1981; Hakim, 1987; Hossmann, 1994). Therefore, the ischemic penumbra can be rescued from infarction if flow is reestablished (e.g., Z hang and Iadecola, 1993; Overgard et al., 1994; Zhang et al., 1994). On the other hand, if the flow reduction becomes more severe, or if the metabolic state of the tissue worsens, the penumbra undergoes infarction (e.g., Huang et al., 1996; Kim et al., 1996). Therefore, the observation that penumbral $\mathrm{CBF}$ is reduced to a greater extent in APP transgenics than in wild-type mice suggests that vascular factors play a role in the increased susceptibility to ischemic damage of APP transgenics.

To study the mechanisms by which APP leads to more severe oligemia in the penumbra, we studied cerebral vascular reactivity in the APP transgenics. We found that the vasodilation produced by neocortical application of $\mathrm{ACh}$, a response mediated by local release of endothelial nitric oxide (Faraci, 1992; Wei et al., 1992), is reduced in these mice. The effect cannot be attributed to a nonspecific loss in vascular reactivity or to an impairment of the response of vascular smooth muscles to nitric oxide, because the vasodilation produced by the nitric oxide donor SNAP was not affected. These observations suggest that endothelial-dependent vascular responses are impaired in APP transgenics. This finding is in agreement with data demonstrating that in the rat aorta, endogenous $\mathrm{A} \beta$ reduces the vascular reactivity to acetylcholine

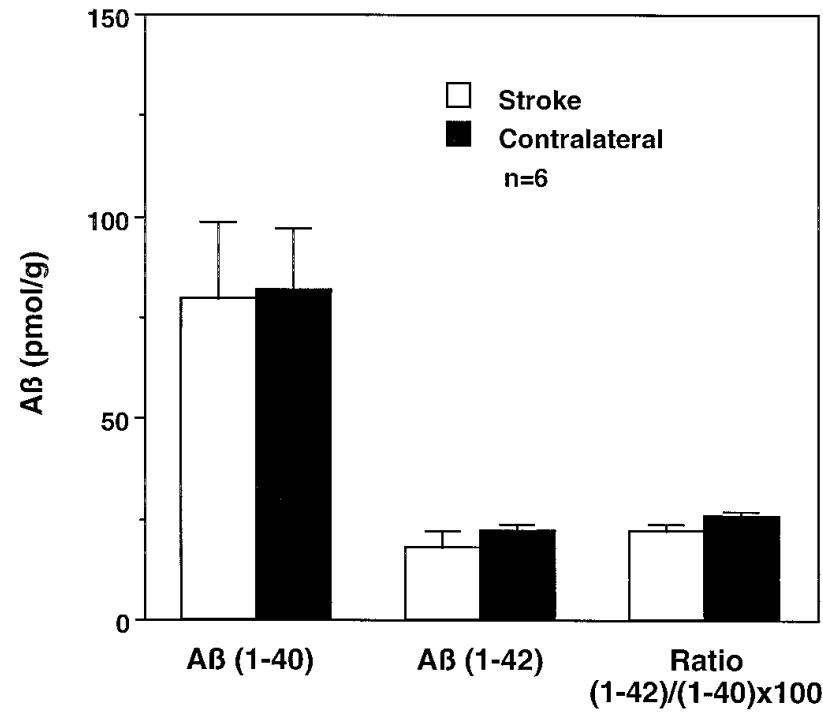

Figure 3. Effect of MCA occlusion on $\mathrm{A} \beta$ concentration in the ischemic territory in $\mathrm{FVB} / \mathrm{N}$ transgenic mice overexpressing $\mathrm{APP}_{695} . \mathrm{SWE}$. A $\beta$ was measured $24 \mathrm{hr}$ after MCA occlusion using an ELISA-based method (for details, see Materials and Methods). Transgene-derived A $\beta$ [(1-40), $(1-42)]$ was present in the brain. However, the $\mathrm{A} \beta$ concentration did not differ between ischemic and nonischemic hemispheres $(p>0.05$, paired $t$ test). The ratio between the $1-40$ and $1-42$ peptides $[(1-42) /(1-$ 40) $\times 100$ ] also did not change. 

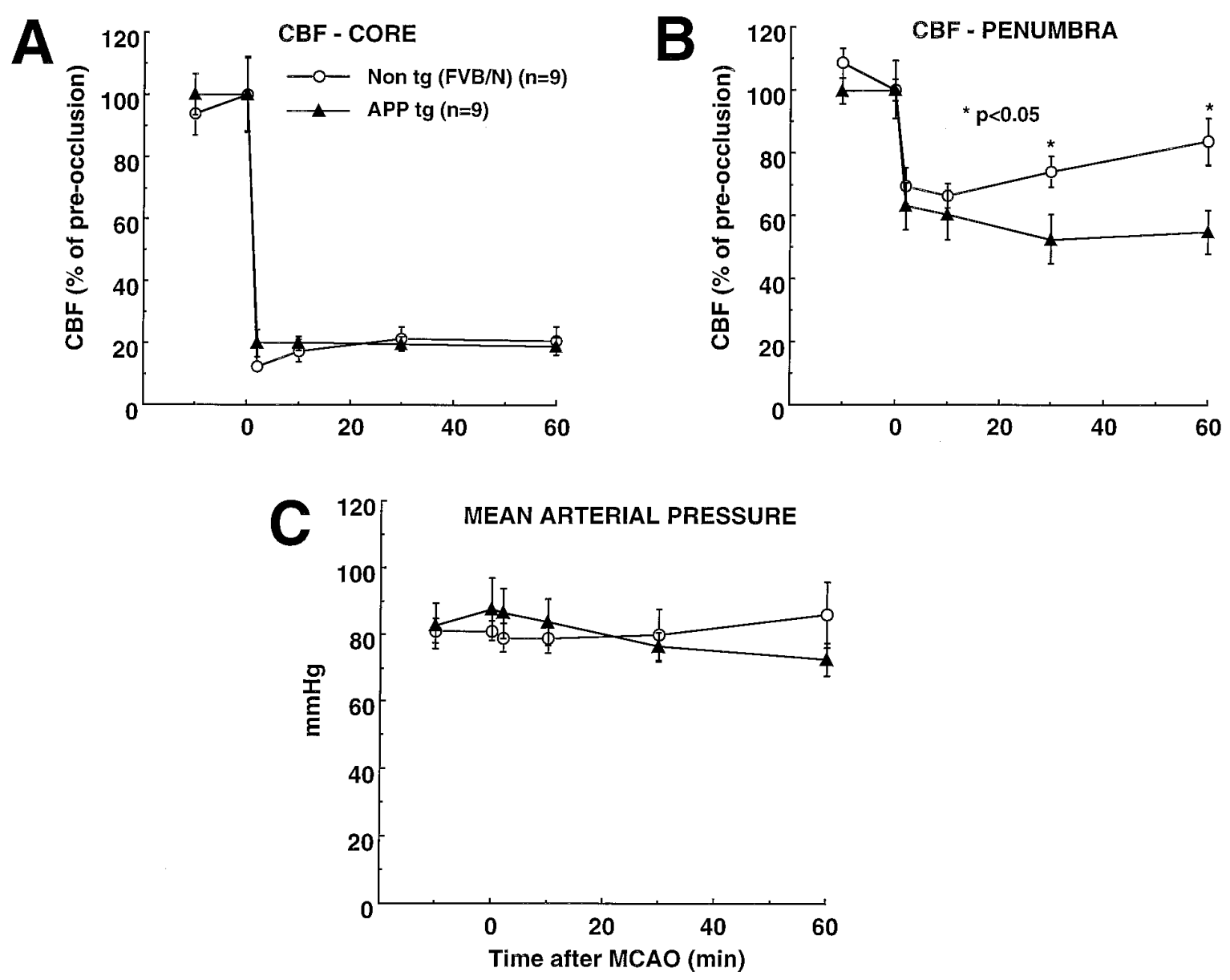

Figure 4. Effect of MCA occlusion on $\mathrm{CBF}$ in $\mathrm{FVB} / \mathrm{N}$ transgenic mice overexpressing $\mathrm{APP}_{695} . \mathrm{SWE}$ and nontransgenic littermates. $A$, The reduction in $\mathrm{CBF}$ in the center of the ischemic core is not different between transgenic and nontransgenic mice. $B$, In the ischemic penumbra, however, $\mathrm{CBF}$ is relatively more reduced in APP transgenics $(p<0.05, t$ test). $C$, Mean arterial pressure is not different between APP transgenics and nontransgenic littermates.

(Thomas et al., 1996). Therefore, one possibility is that $\mathrm{A} \beta$ disrupts cerebral vascular regulation and impairs the reactivity of the cerebral circulation to selected vasodilator stimuli. Such loss of vascular reactivity could explain the depression of CBF in the penumbral region of the infarct found in the APP transgenics. After MCA occlusion, flow to the regions surrounding the ischemic core is provided through collateral vessels from the adjacent nonischemic brain. Collateral flow develops because of vasodilatation of arterioles at the infarct border, a process that favors redistribution of flow toward the ischemic region (Iadecola, 1997). It is likely, therefore, that the loss of endotheliumdependent vascular reactivity in APP transgenics prevents the formation of an effective collateral circulation and results in more severe ischemia in vulnerable regions of the ischemic penumbra. It remains to be determined, however, whether other aspects of cerebral endothelial function, such as the blood-brain barrier, are also altered in APP transgenics and whether such alteration contributes to their increased susceptibility to cerebral ischemia. The observation that the ischemic swelling does not differ between transgenic and nontransgenic mice suggests that the increase in cerebrovascular permeability that accompanies cerebral ischemia is not enhanced further by APP overexpression. Further studies will be required to investigate blood-brain barrier function in APP transgenics.
On the other hand, the increased susceptibility to ischemic damage in APP transgenics could also result from direct neurotoxic effects of $\mathrm{A} \beta$ on the postischemic brain. We have shown here that transgene-derived $A \beta$ is present in a relatively high concentration in the brain of APP mice. There is evidence that $\mathrm{A} \beta$ is neurotoxic and promotes excitotoxicity, effects mediated through free radical formation and perturbation of ionic homeostasis (Mattson et al., 1993a; Fraser et al., 1997). Elevated levels of $\mathrm{A} \beta$ could, therefore, worsen brain damage by amplifying the pathogenic processes that occur during cerebral ischemia. An important question is whether the flow reduction in penumbra is secondary to the exacerbation of the tissue damage by $\mathrm{A} \beta$. For the following reasons, however, this possibility is unlikely. First, the presence of impaired endothelium-dependent vascular reactivity in nonischemic APP transgenics argues strongly that the cerebrovascular dysfunction is a direct consequence of a vascular action of $\mathrm{A} \beta$ and not a secondary effect of ischemic damage. Second, the worsening of penumbral blood flow occurs within 30 min of induction of ischemia, at a time when cerebral ischemic damage is still in its early stages (Dereski et al., 1993; Garcia et al., 1993). Therefore, secondary vascular effects from tissue damage are unlikely at this time. Third, in mice in which there is an increase in focal ischemic brain damage attributed to direct neurotoxicity, for example in superoxide dismutase null mice, no 


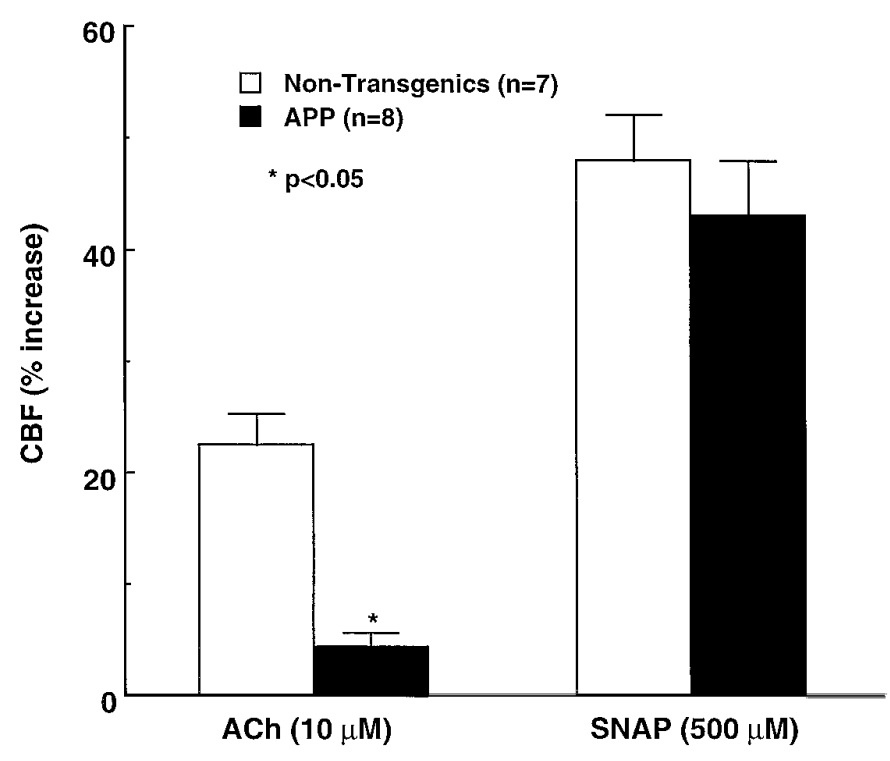

Figure 5. Effect of topical cortical application of ACh or SNAP on the CBF in APP transgenics and nontransgenic littermates. Mice were anesthetized and artificially ventilated. End-tidal $\mathrm{CO}_{2}$ was monitored and maintained between 2.2 and $2.6 \%$, a value that corresponded at a $\mathrm{P}_{\mathrm{CO}_{2}}$ of $35-38 \mathrm{mmHg}$ (see Materials and Methods). Arterial pressure was $94 \pm 8$ $\mathrm{mmHg}$ in APP transgenics and $84 \pm 6$ in nontransgenics. The vasodilatation produced by ACh was markedly reduced in APP transgenics $(p<$ $0.001, t$ test), whereas the response to SNAP was not statistically different between transgenic and nontransgenic mice.

effects on flow were observed (Kondo et al., 1997). These observations suggest that secondary effects of $\mathrm{A} \beta$-mediated neurotoxicity on vascular function are unlikely.

In conclusion, we have demonstrated that MCA occlusion in transgenic mice overexpressing APP produces infarcts that are larger than in nontransgenic controls. Although the $\mathrm{A} \beta$ peptide is present in the brain of APP transgenics, cerebral ischemia does not enhance APP cleavage and does not increase A $\beta$ accumulation. In addition, MCA occlusion produces a more severe $\mathrm{CBF}$ reduction in the ischemic penumbra of APP transgenics than in wild-type controls. This effect is related to a substantial loss in endotheliumdependent vascular reactivity in the transgenics. The data demonstrate that APP overexpression increases the susceptibility of the brain to ischemic damage. The effect is likely to involve both transgene-derived $\mathrm{A} \beta$ neurotoxicity and $\mathrm{A} \beta$-induced vascular dysfunction, resulting in more severe ischemia in regions at risk for infarction. The combination of these factors, therefore, contributes to the exacerbation of ischemic brain damage. The vascular actions of APP metabolites have to be taken into account in studies of the role of APP in neurodegeneration and neurotoxicity.

\section{REFERENCES}

Abe K, Tanzi RE, Kogure K (1991a) Induction of HSP70 mRNA after transient ischemia in gerbil brain. Neurosci Lett 125:166-168.

Abe K, Tanzi RE, Kogure K (1991b) Selective induction of Kunitz-type protease inhibitor domain-containing amyloid precursor protein mRNA after persistent focal ischemia in rat cerebral cortex. Neurosci Lett 125:172-174.

Astrup J, Siesjö BK, Symon L (1981) Thresholds in cerebral ischemiathe ischemic penumbra. Stroke 6:723-725.

Banati RB, Gehrmann J, Wiessner C, Hossmann KA, Kreutzberg GW (1995) Glial expression of the beta-amyloid precursor protein (APP) in global ischemia. J Cereb Blood Flow Metab 15:647-654.

Barone FC, Knudsen DJ, Nelson AH, Feuerstein GZ, Willette RN (1993) Mouse strain differences in susceptibility to cerebral ischemia are related to cerebral vascular anatomy. J Cereb Blood Flow Metab 13:683-692.

Chan PH, Kamii H, Yang G, Gafni J, Epstein CJ, Carlson E, Reola L (1993) Brain infarction is not reduced in SOD-1 transgenic mice after a permanent focal cerebral ischemia. NeuroReport 5:293-296.

Dalkara T, Irikura K, Huang Z, Panahian N, Moskowitz (1995) Cerebrovascular responses under controlled and monitored physiological conditions in the anesthetized mice. J Cereb Blood Flow Metab 15:631-638.

Dereski MO, Chopp M, Knight RA, Rodolosi LC, Garcia JH (1993) The heterogeneous temporal evolution of focal ischemic neuronal damage in the rat. Acta Neuropathol (Berl) 85:327-333.

Faraci F (1992) Regulation of the cerebral circulation by endothelium. Pharmacol Ther 56:1-22.

Fraser SP, Suh Y-H, Djamgoz MBA (1997) Ionic effects if the Alzheimer's disease $\beta$-amyloid precursor protein and its metabolic fragments. Trends Neurosci 20:67-72.

Games D, Adams D, Alessandrini R, Barbour R, Berthelette P, Blackwell C, Carr T, Clemens J, Donaldson T, Gillespie F, Guido T, Hagopian S, Johnson-Wood K, Khan K, Lee M, Leibowitz P, Lieberburg I, Little S, Masliah E, McConlogue L, Montoya-Zavala M, Mucke L, Paganini L, Penniman E (1995) Alzheimer-type neuropathology in transgenic mice overexpressing V717F beta-amyloid precursor protein. Nature 373:523-527.

Garcia JH, Yoshida Y, Chen H, Li Y, Zhang ZG, Lian J, Chen S, Chopp M (1993) Progression from ischemic injury to infarct following middle cerebral artery occlusion in the rat. Am J Pathol 142:623-635.

Gravina SA, Ho L, Eckman CB, Long KE, Otvos LJ, Younkin LH, Suzuki N, Younkin SG (1995) Amyloid beta protein (A beta) in Alzheimer's disease brain. Biochemical and immunocytochemical analysis with antibodies specific for forms ending at A beta 40 or A beta 42(43). J Biol Chem 270:7013-7016.

Hakim AM (1987) The cerebral ischemic penumbra. Can J Neurol Sci 14:557-559.

Heistad D, Kontos H (1983) Cerebral circulation. In: Handbook of physiology: the cardiovascular system III (Abboud F, Shephard J, eds), pp 137-182. Bethesda, MD: American Physiological Society.

Higgins LS, Rodems JM, Catalano R, Quon D, Cordell B (1995) Early Alzheimer disease-like histopathology increases in frequency with age in mice transgenic for beta-APP751. Proc Natl Acad Sci USA 92:4402-4406.

Hossmann K-A (1994) Viability thresholds and the penumbra of focal ischemia. Ann Neurol 36:557-565.

Hsiao KK, Borchelt DR, Olson K, Johannsdottir R, Kitt C, Yunis W, Xu S, Eckman C, Younkin S, Price D, Iadecola C, Clark HB, Carlson G (1995) Age-related CNS disorder and early death in transgenic FVB/N mice overexpressing Alzheimer amyloid precursor proteins. Neuron 15:1203-1218.

Hsiao KK, Chapman P, Nilsen S, Eckman C, Harigaya Y, Younkin S, Yang F, Cole G (1996) Correlative memory deficits, A $\beta$ elevation, and amyloid plaques in transgenic mice. Science 274:99-102.

Huang A, Huang PL, Ma J, Meng W, Ayata C, Fishman MC, Moskowitz MA (1996) Enlarged infarcts in endothelial nitric oxide synthase knockout mice are attenuated by nitro-L-arginine. J Cereb Blood Flow Metab 16:981-987.

Iadecola C (1992) Does nitric oxide mediate the increases in cerebral blood flow elicited by hypercapnia? Proc Natl Acad Sci USA 89:3913-3916.

Iadecola C (1997) Cerebral circulatory dysregulation in ischemia. In: Cerebrovascular diseases (Ginsberg MD, Bogousslavsky J, eds). Cambridge, MA: Blackwell Science, in press.

Iadecola C, Zhang F (1996) Permissive and obligatory roles of NO in cerebrovascular responses to hypercapnia and acetylcholine. Am J Physiol 271:990-1001.

Iadecola C, Zhang F, Xu X (1995) Inhibition of inducible nitric oxide synthase ameliorates cerebral ischemic damage. Am J Physiol 268:286-292.

Kalaria RN, Bhatti SU, Palatinsky EA, Pennington DH, Shelton ER, Chan HW, Perry G, Lust WD (1993) Accumulation of the beta amyloid precursor protein at sites of ischemic injury in rat brain. NeuroReport 4:211-214.

Kim Y, Busto R, Dietrich WD, Kraydieh S, Ginsberg MD (1996) Delayed postischemic hyperthermia in awake rats worsens the histopathological outcome of transient focal cerebral ischemia. Stroke 27:2274-2280. 
Kondo T, Reaume AG, Huang T-T, Carlson E, Murakami K, Chen SF, Hoffman EK, Scott RW, Epstein CJ, Chan PH (1997) Reduction of $\mathrm{CuZn}$-superoxide dismutase activity exacerbates neuronal cell injury and edema formation after transient focal cerebral ischemia. J Neurosci 17:4180-4189.

Lendon CL, Ashall F, Goate AM (1997) Exploring the etiology of Alzheimer disease using molecular genetics. JAMA 277:825-831.

Lin TN, He YY, Wu G, Khan M, Hsu CY (1993) Effect of brain edema on infarct volume in a focal cerebral ischemia model in rats. Stroke 24:117-121.

Mattson MP, Barger SW, Cheng B, Lieberburg I, Smith SV, Rydel RE (1993a) beta-Amyloid precursor protein metabolites and loss of neuronal $\mathrm{Ca} 2+$ homeostasis in Alzheimer's disease. Trends Neurosci 16:409-414.

Mattson MP, Cheng B, Culwell AR, Esch FS, Lieberburg I, Rydel RE (1993b) Evidence for excitoprotective and intraneuronal calciumregulating roles for secreted forms of the beta-amyloid precursor protein. Neuron 10:243-254.

Mattson MP, Barger SW, Furukawa K, Bruce AJ, Wyss CT, Mark RJ, Mucke L (1997) Cellular signaling roles of TGF beta, TNF alpha and beta APP in brain injury responses and Alzheimer's disease. Brain Res Rev 23:47-61.

Overgard K, Sereghy T, Pedersen H, Boysen G (1994) Effect of delayed thrombolysis with rt-PA in a rat embolic stroke model. J Cereb Blood Flow Metab 14:472-477.

Price DL, Sisodia SS (1994) Cellular and molecular biology of Alzheimer's disease and animal models. Annu Rev Med 45:435-446.

Saido TC, Yokota M, Maruyama K, Yamao HW, Tani E, Ihara Y, Kawashima S (1994) Spatial resolution of the primary betaamyloidogenic process induced in postischemic hippocampus. J Biol Chem 269:15253-15257.

Selkoe DJ, Yamazaki T, Citron M, Podlisny MB, Koo EH, Teplow DB, Haass C (1996) The role of APP processing and trafficking pathways in the formation of amyloid beta-protein. Ann NY Acad Sci 777:57-64.

Smith SV, Pettigrew LC, Craddock SD, Culwell AR, Rydel RE, Mattson MP (1994) Secreted forms of beta-amyloid precursor protein protect against ischemic brain injury. J Neurochem 63:781-784.
Sobey CG, Faraci FM (1997) Effects of a novel inhibitor of guanylyl cyclase on dilator responses of mouse cerebral arterioles. Stroke 28:837-843.

Stephenson DT, Rash K, Clemens JA (1992) Amyloid precursor protein accumulates in regions of neurodegeneration following focal cerebral ischemia in the rat. Brain Res 593:128-135.

Suzuki N, Cheung TT, Cai XD, Odaka A, Otvos LJ, Eckman C, Golde TE, Younkin SG (1994) An increased percentage of long amyloid beta protein secreted by familial amyloid beta protein precursor (beta APP717) mutants. Science 264:1336-1340.

Thomas T, Thomas G, McLendon C, Sutton T, Mullan M (1996) $\beta$ Amyloid-mediated vasoactivity and vascular endothelial damage. Nature 380:168-171.

Wakita H, Tomimoto H, Akiguchi I, Ohnishi K, Nakamura S, Kimura J (1992) Regional accumulation of amyloid beta/A4 protein precursor in the gerbil brain following transient cerebral ischemia. Neurosci Lett 146:135-138.

Wei EP, Kukreja R, Kontos HA (1992) Effects in cats of inhibition of nitric oxide synthesis on cerebral vasodilation and endothelium-derived relaxing factor from acetylcholine. Stroke 23:1623-1628.

Yokota M, Saido TC, Tani E, Yamaura I, Minami N (1996) Cytotoxic fragment of amyloid precursor protein accumulates in hippocampus after global forebrain ischemia. J Cereb Blood Flow Metab $16: 1219-1223$

Zhang F, Iadecola C (1992) Stimulation of the fastigial nucleus enhances EEG recovery and reduces tissue damage after focal cerebral ischemia. J Cereb Blood Flow Metab 12:962-970.

Zhang F, Iadecola C (1993) Fastigial stimulation increases ischemic blood flow and reduces brain damage after focal ischemia. J Cereb Blood Flow Metab 13:1013-1019.

Zhang F, Iadecola C (1994) Infarct measurement methodology. J Cereb Blood Flow Metab 14:697-698.

Zhang F, White JG, Iadecola C (1994) Nitric oxide donors increase blood flow and reduce brain damage in focal ischemia: evidence that nitric oxide is beneficial in the early stages of cerebral ischemia. J Cereb Blood Flow Metab 14:217-226. 